Eur. J. Clin. Chem. Clin. Biochem.

Vol. 31, 1993, pp. 347-351

(C) 1993 Walter de Gruyter \& Co.

Berlin - New York

\title{
Influence of Dopaminergic Agonists/Antagonists on Fucose Metabolism in the Rat Brain
}

\author{
By B. Hocher ${ }^{1,2}$, Faikah Abou-Rebyeh ${ }^{1}$ and Ch. Bauer ${ }^{1}$ \\ 1 Institut für Molekularbiologie und Biochemie \\ ${ }^{2}$ Abteilung für Innere Medizin, Universitätsklinikum Steglitz \\ Freie Universität Berlin, Berlin, Germany
}

(Received January 4/March 30, 1993)

Summary: Valid indications of a key role for dopaminergic drugs in glycoprotein fucosylation in neuronal tissue in vitro led us to investigate whether the administration of dopaminergic agonists/antagonists influences fucose metabolism in the rat brain in vivo. Three test groups were set up. Group 1 was given $L$-DOPA $(210 \mathrm{mg} / \mathrm{l})$, Group 2 haloperidol $(10.5 \mathrm{mg} / \mathrm{l})$ in drinking water, Group 3 served as control. The rats were sacrificed after 8 weeks and enzyme activities in 5 different brain areas were determined concerning the enzymes of the anabolic fucose metabolism: fucokinase, fucose-1-phosphate pyrophosphorylase and fucosyltransferase 1 and 2. Only the specific activity of fucokinase was affected by haloperidol or $L$-DOPA administration. In the olfactory bulbus, thalamus and cortex, haloperidol decreased fucokinase activity by $21 \%, 37 \%$, and $39 \%$, respectively ( $p<0.05$ in each case). No changes were observed in the cerebellum and striatum. Surprisingly, fucokinase activity in the cortex was decreased by $L$-DOPA $(31 \%, p<0.05)$.

Conclusions: Cerebral fucokinase activity is influenced in vivo by dopaminergic drugs in well circumscribed brain areas. Other enzymes of the anabolic fucose metabolism showed no change in activity. It is, therefore, conceivable that these drugs, apart from known mechanisms, exert part of their pharmacological action via a modulation of fucose metabolism.

\section{Introduction}

$L$-Fucose (like $\mathrm{N}$-acetylneuraminic acid and sometimes also $\mathrm{N}$-acetyl- $D$-glucosamine and $D$-galactose) is a terminal sugar of numerous glycoconjugates $(1$, 2). Fucosylated glycoproteins are thought to play an essential role in the formation of long-term memory traces in the rat brain $(3,4)$. A similar conclusion can

\footnotetext{
1) Enzymes:

Fucokinase EC 2.7.1.52

Fucose-1-phosphate pyrophosphorylase = fucose-1-phosphate gyanylyltransferase; GTP : fucose-1-phosphate gyanylyltransferase EC 2.7.7.30

Fucosyltransferase 1, GDP-fucose : asialoglycoprotein fucosyltransferase $=$ galactoside $2-\alpha-L$-fucosyltransferase $\mathrm{EC}$ 2.4.1.69

Fucosyltransferase 2, GDP-fucose : asialogalactoglycoprotein fucosyltransferase.
}

be drawn from experiments with chicks (5). Furthermore, fucosylation inhibition by 2-deoxy- $D$-galactose $(6,7)$ caused amnesia in trained rats and chicks $(8$, 9). The cellular mechanisms mediating enhanced fucose incorporation in the course of memory formation are still poorly understood. It has been shown that glycoprotein fucosylation can be stimulated by dopamine receptor agonists in vitro (10). We therefore investigated whether a long-term supply of dopaminergic agonists/antagonists ( $L$-DOPA and haloperidol) to the rat brain in vivo influences the activity of key enzymes ${ }^{1}$ ) of fucose anabolism (fig. 1): fucokinase, fucose-1-phosphate-pyrophosphorylase, GDP-fucose: asialoglycoprotein fucosyltransferase (fucosyltransferase 1) and GDP-fucose: asialoagalactoglycoprotein fucosyltransferase (fucosyltransferase 2). 


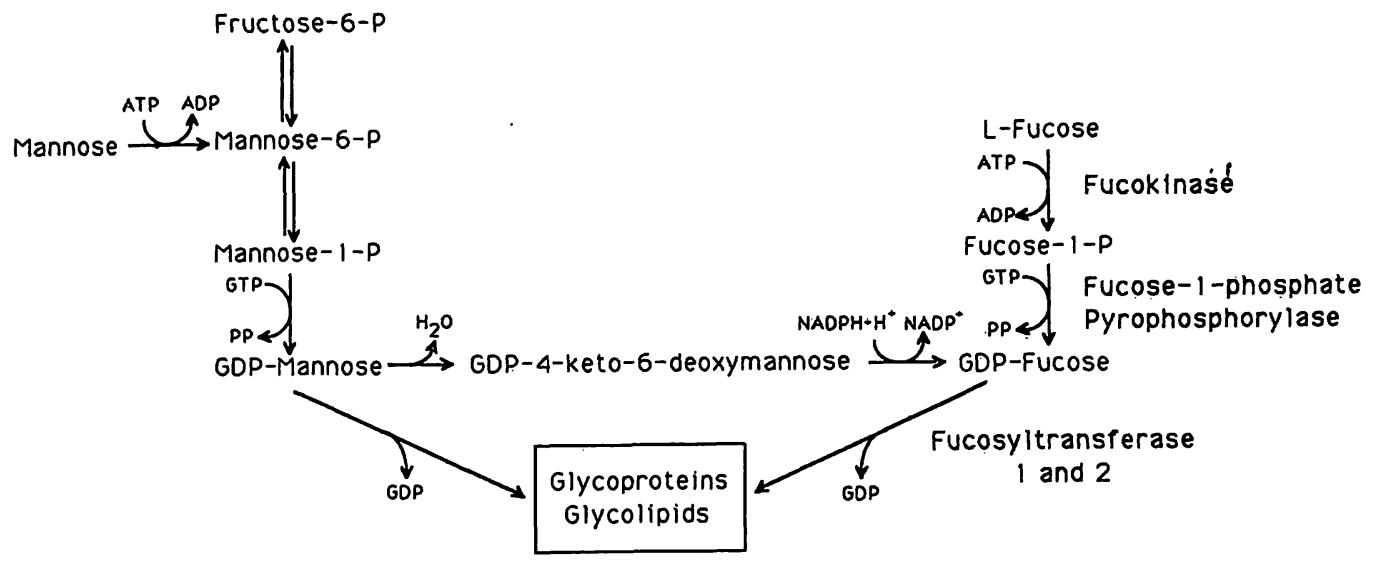

Fig. 1. Anabolic $L$-fucose metabolism in the rat brain. The synthesis of fucosylated glycoproteins starting from the precursor fructose-6-phosphate seems to be of minor importance in the rat brain.

\section{Materials and Methods}

\section{Materials}

Unless otherwise stated, all reagents were of analytical grade and were purchased from Merck (Darmstadt, Germany) and Sigma (München, Germany). $\left[{ }^{14} \mathrm{C}\right] L$-Fucose and GDP- $L-$ $\left[{ }^{14} \mathrm{C}\right]$ fucose were from Amersham (Arlington, Great Britain). $L$ $\left[1-{ }^{14} \mathrm{C}\right]$ fucose-1-phosphate was prepared in our laboratory using GDP-L $-\left[{ }^{14} \mathrm{C}\right]$ fucose as starting material.

\section{Enzyme assays}

\section{Fucokinase assay}

Enzyme activity was determined as described earlier (11). Briefly, the tissue was homogenized in nine volumes of assay buffer using a Dounce homogenizer, and the homogenate thus obtained was centrifuged at $40000 \mathrm{~g}$ for $30 \mathrm{~min}$. The supernatant served as a crude enzyme source for the fucokinase (and for fucose-1-phosphate pyrophosphorylase as well). The reaction mixture contained (in a final volume of $0.15 \mathrm{ml}$ ) $5 \mathrm{~g} / \mathrm{l}$ Triton X-100, $30 \mathrm{mmol} / \mathrm{l} \mathrm{MgCl}_{2}, 10 \mathrm{mmol} / \mathrm{l}$ phosphoenolpyruvate, $\mathrm{pH} 7.0,10 \mathrm{mmol} / \mathrm{l} \mathrm{ATP}, \mathrm{pH} 7.0,0.5 \mathrm{U}$ of pyruvate kinase, $50 \mathrm{mmol} / 1 \mathrm{Tris}-\mathrm{HCl}, \mathrm{pH} 7.4,30 \mathrm{mmol} / \mathrm{l} \mathrm{NaCl}, 20 \mathrm{mmol} / \mathrm{l} L-$ fucose and $0.4 \mathrm{~mol} / 1\left[{ }^{14} \mathrm{C}\right] L$-fucose. The assay was started by addition of the crude enzyme preparation; after incubation of $37^{\circ} \mathrm{C}$ for $20 \mathrm{~min}$, the reaction was stopped by addition of cold ethanol $(970 \mathrm{ml} / \mathrm{l})$. After centrifugation at $20000 \mathrm{~g}$ for $10 \mathrm{~min}$, an aliquot of the resulting supernatant was applied to Whatman $3 \mathrm{MM}$ paper, and the different fucose metabolites formed were separated by using the following solvent system: n-propanol/ $\mathrm{Na}\left(\mathrm{CH}_{3} \mathrm{COO}\right), 1 \mathrm{~mol} / \mathrm{l} / \mathrm{H}_{2} \mathrm{O}(7+1+1$, by vol. $)$ according to Levin \& Wei (12).

\section{Fucose-1-phosphate pyrophosphorylase assay}

The assay mixture contained (in a final volume of $0.1 \mathrm{ml}$ ) 100 mmol/1 Tris- $\mathrm{HCl}, \mathrm{pH} 7.4,5 \mathrm{mmol} / 1 \mathrm{MgCl}_{2}, 40 \mathrm{mmol} / \mathrm{l}$ nicotinic acid, $10 \mathrm{~g} / 1$ Triton $X-100,10 \mathrm{mmol} / 1 \mathrm{GTP}, 10 \mathrm{mmol} / 1$ fucose1-phosphate, and $0.8 \mu \mathrm{mol} / 1 L-\left[1-{ }^{14} \mathrm{C}\right]$ fucose-1-phosphate. The reaction was started by addition of the crude enzyme preparation (as described above). After incubation for $20 \mathrm{~min}$ at $37^{\circ} \mathrm{C}$, the reaction was stopped by addition of cold ethanol $(970 \mathrm{ml} / \mathrm{l})$. After centrifugation at $20000 \mathrm{~g}$ for $10 \mathrm{~min}$, the supernatant was analyzed by paper chromatography using the following solvent system: $\mathrm{C}_{2} \mathrm{H}_{5} \mathrm{OH} / \mathrm{NH}_{3}\left(\mathrm{CH}_{3} \mathrm{COO}\right), 1 \mathrm{~mol} / 1$ $(5+2$, by vol.) (13).

\section{Fucosyltransferase assay}

The activity of the GDP-fucose : glycoprotein fucosyltransferases was determined by measuring the incorporation rate of $\left[{ }^{14} \mathrm{C}\right]$ fucose from the nucleotide sugar GDP-L- $-\left[{ }^{14} \mathrm{C}\right]$ fucose into desialylated fetuin (fucosyltransferase 1) and desialodegalactofetuin (fucosyltransferase 2). In a final volume of $0.15 \mathrm{ml}$, the reaction mixture contained $2 \mathrm{mmol} / \mathrm{l} \mathrm{MgCl}, 0.4 \mathrm{mmol} / \mathrm{l}$ ATP, $1.85 \mathrm{kBq}(0.05 \mu \mathrm{Ci}) \mathrm{GDP}-L-\left[{ }^{14} \mathrm{C}\right]$ fucose, $5 \mathrm{mmol} / 1 \mathrm{GDP}-L$-fucose, $0.5 \mathrm{mg}$ acceptor (desialylated fetuin or desialodegalactofetuin), $1.5 \mathrm{~g} / \mathrm{l}$ Triton $\mathrm{X}-100$ and $0.1 \mathrm{mg}$ of sample protein from the homogenate before it was subjected to centrifugation (see above). The reaction mixture was incubated for $60 \mathrm{~min}$ at $37^{\circ} \mathrm{C}$ and pipetted onto filter paper discs that had been mounted on pins. The discs were air-dried and washed twice for $30 \mathrm{~min}$ each with $100 \mathrm{~g} / \mathrm{l}$, with $50 \mathrm{~g} / \mathrm{l}$ trichloroacetic acid and then with ethanol/water, volume fraction $0.5(14,15)$. Radioactivity was determined by counting the discs in a toluene scintillation mixture.

\section{Animals}

The investigation was performed using male Wistar rats weighing $200 \mathrm{~g}$. Three test groups were set up. Group 1 was given $L$ DOPA $(210 \mathrm{mg} / \mathrm{l})$, Group 2 haloperidol $(10.5 \mathrm{mg} / \mathrm{l})$ in drinking water, while Group 3 served as control. Drinking water was changed every 2 hours to prevent breakdown of the drugs. After 8 weeks the rats were sacrificed, and the enzymatic activity of fucokinase, fucose-1-phosphate pyrophosphorylase and GDP-fucose as well as of glycoprotein fucosyltransferases, were determined in 5 different areas (olfactory bulbus, striatum, thalamus, cerebellum and cortex) carefully dissected from the total brain.

\section{Statistics}

All data are reported as $\bar{x} \pm S D$ and were analysed using Student's t-test.

\section{Results}

Rats treated with haloperidol or $L$-DOPA showed no weight loss as compared to controls. Enzyme activity differed considerably in the various brain areas of untreated control rats (figs 2-5). Fucose-1-phosphate pyrophosphorylase activity increased as follows: thal- 
amus $<$ olfactory bulbus $=$ cortex $<$ striatum $=$ cerebellum (fig. 3). Fucosyltransferase 1 activity, on the other hand, was quite similar in the different areas of the rat brain (fig. 4). Fucosyltransferase 2 activity

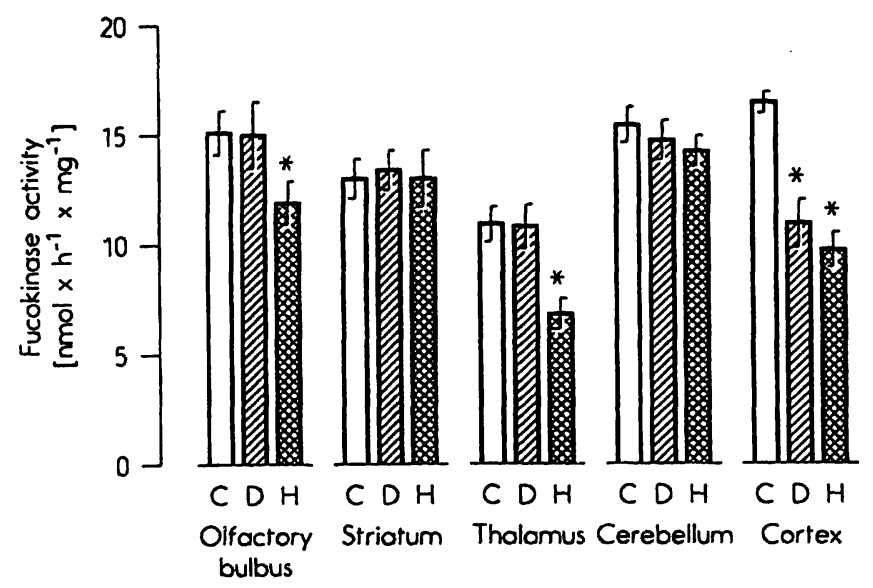

Fig. 2. Effect of haloperidol (H) and $L$-DOPA (D) administration on fucokinase activity in different areas of the rat brain (olfactory bulbus, striatum, thalamus, cerebellum and cortex) in vivo. Haloperidol selectively inhibited fucokinase activity in the olfactory bulbus, thalamus and cortex by $21 \%, 37 \%$, and $39 \%$ respectively ( $p<0.05$ in each case). An inhibition of fucokinase activity was also seen in the cortex under $L$-DOPA $(p<0.05)$. C: control, $n=7$ in each group.

* indicates significant changes $(p<0.05)$.

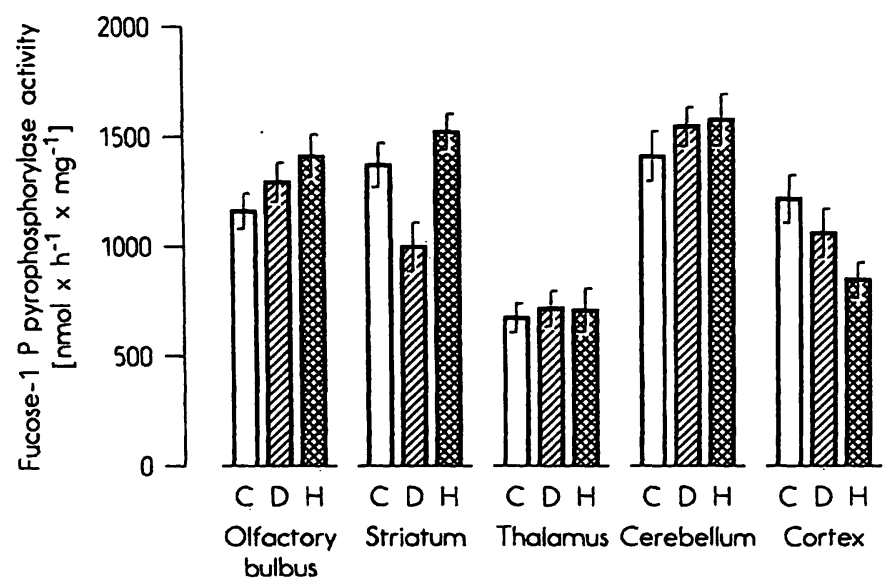

Fig. 3. Effect of haloperidol $(\mathrm{H})$ and $L$-DOPA (D) administration of fucose-1-phosphate pyrophosphorylase activity in the olfactory bulbus, striatum, thalamus, cerebellum and cortex in vivo. C: control, $\mathbf{n}=7$ in each group. was clearly elevated in the cerebellum and nearly equal in the olfactory bulbus, striatum, thalamus and cortex (fig. 5). Fucokinase activity increased in untreated rats as follows: thalamus $<$ striatum $<$ olfactory bulbus $=$ cerebellum $=$ cortex. Fucose-1-phosphate pyrophosphorylase and GDP-fucose : glycoprotein fucosyltransferase activity was not affected significantly by administration of haloperidol or $L$-DOPA

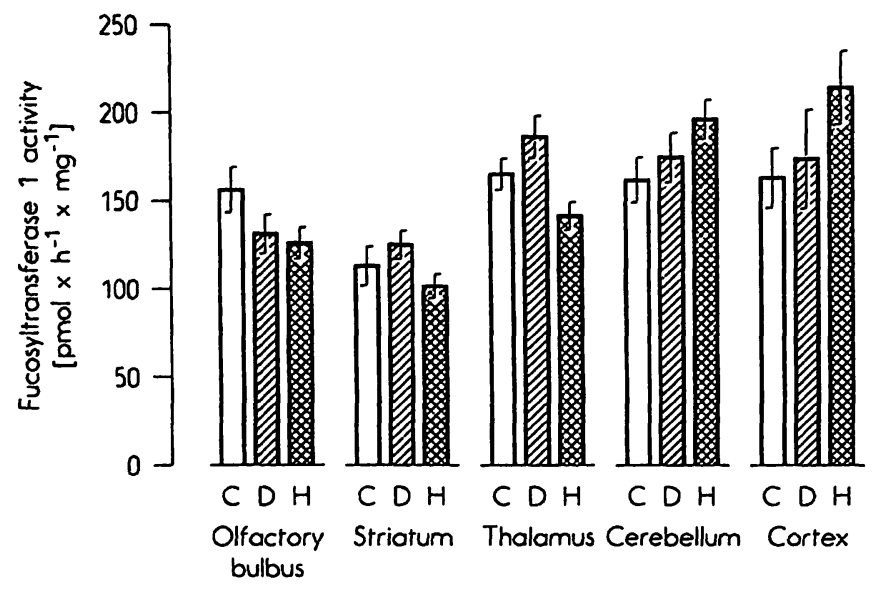

Fig. 4. Effect of haloperidol (H) and L-DOPA (D) administration on fucosyltransferase 1 activity in the olfactory bulbus, striatum, thalamus, cerebellum and cortex in vivo. C: control, $\mathrm{n}=7$ in each group.

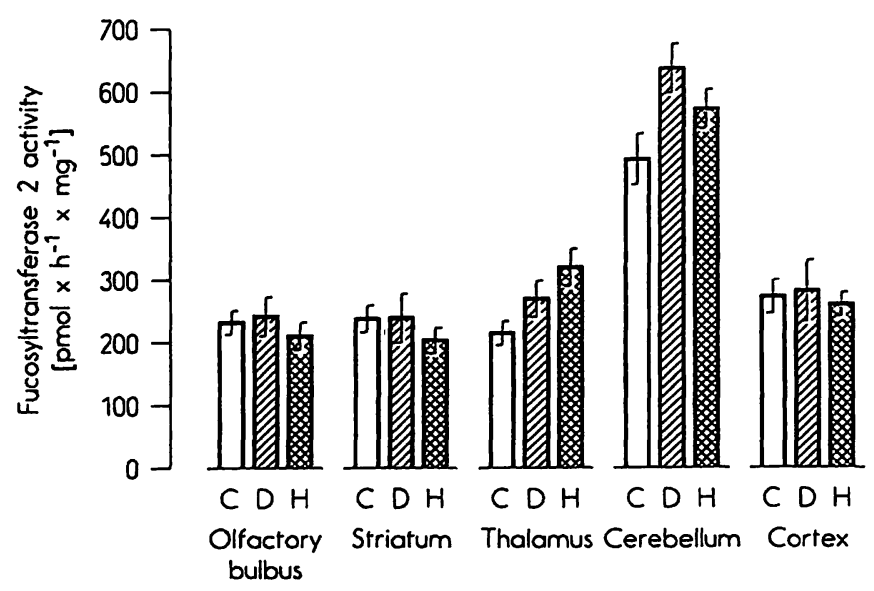

Fig. 5. Effect of haloperidol (H) and $L$-DOPA (D) administration on fucosyltransferase 2 activity in the olfactory bulbus, striatum, thalamus, cerebellum and cortex in vivo. $\mathrm{C}$ : control, $\mathrm{n}=7$ in each group.

Tab. 1. Activity pattern of the different enzymes of the anabolic fucose metabolism in the rat brain with or without dopaminergic agonists in vitro. $(\overline{\mathbf{x}} \pm S D, n=5)$

\begin{tabular}{|c|c|c|c|c|}
\hline & Control & Haloperidol & $\begin{array}{l}L \text {-DOPA } \\
(1 \mathrm{mmol} / \mathrm{l})\end{array}$ & Dopamine \\
\hline \multicolumn{5}{|c|}{ Enzyme activity (nmol $\times \mathrm{h}^{-1} \times \mathrm{mg}^{-1}$ of protein) } \\
\hline $\begin{array}{l}\text { Fucokinase } \\
\text { Fucose-1-P pyrophosphorylase } \\
\text { Fucosyl-transferase } 1 \\
\text { Fucosyl-transferase } 2\end{array}$ & $\begin{array}{c}15.3 \pm 0.9 \\
1246 \pm 97 \\
0.17 \pm 0.02 \\
0.50 \pm 0.05\end{array}$ & $\begin{array}{c}15.3 \pm 1.0 \\
1296 \pm 201 \\
0.16 \pm 0.02 \\
0.55 \pm \quad 0.05\end{array}$ & $\begin{array}{c}16.0 \pm 1.2 \\
1305 \pm 137 \\
0.17 \pm 0.03 \\
0.51 \pm 0.06\end{array}$ & $\begin{array}{c}14.9 \pm 1.5 \\
1200 \pm 97 \\
0.16 \pm 0.02 \\
0.50 \pm 0.07\end{array}$ \\
\hline
\end{tabular}


in vivo (figs $3-5$ ). Haloperidol selectively decreased fucokinase activity (fig. 2) in the olfactory bulbus, thalamus and cortex by $21 \%, 37 \%$, and $39 \%$ respectively ( $p<0.05$ in each case). A decrease of fucokinase activity in the cortex was also seen with $L$-DOPA $(31 \%, \mathrm{p}<0.05)$.

Direct addition of dopaminergic agonists/antagonists ( $L$-DOPA, dopamine or haloperidol, $1 \mathrm{mmol} / 1$ in each case) to the enzyme assays did not alter the enzymatic activity in vitro (tab. 1).

\section{Discussion}

Fucosylated glycoproteins in the rat brain seem to play an essential role in memory formation $(3,8,9)$. GDP-fucose as a substrate for the different fucosyltransferases is mainly synthesized from $L$-fucose via the fucokinase and fucose-1-phosphate pyrophosphorylase reaction. According to our present data, the de novo synthesis of $L$-fucose starting from the precursor fructose-6-phosphate seems to be of minor importance in the rat brain, as the activity of the enzyme involved in the conversion of GDP-mannose via GDP-4-keto-6-deoxymannose to GDP-fucose was less than $5 \%$ compared to the activity of fucokinase or fucose-1-phosphate pyrophosphorylase in the rat brain in vivo (unpublished data from Prof. Dr. $C h$. Bauer, Berlin). Fucosylation is influenced in vitro by dopaminergic drugs $(10,16,17)$. Our data clearly demonstrate for the first time that the activity of cerebral fucokinase, but not of fucose-1-phosphate pyrophosphorylase and GDP-fucose : glycoprotein fucosyltransferase, is influenced in vivo by haloperidol (dopaminergic receptor antagonist) in well-circumscribed brain areas (figs. 2-5). Cerebral fucokinase, therefore, may be the target enzyme of dopaminergic drugs that regulate or modulate fucosylation of gly-

\section{References}

1. Kornfeld, R. \& Kornfeld, S. (1976) Comparative aspects of glycoprotein structure. Annu. Rev. Biochem. 45, 217237.

2. Hartel-Schenk, S., Minnifield, N., Reutter, W., Hanski, Ch., Bauer, Ch. \& Morre, D. J. (1991) Distribution of glycosyltransferases among Golgi apparatus subfractions from liver and hepatomas of the rat. Biochim. Biophys. Acta 1115, $108-122$.

3. Pohle, W., Acosta, L., Rüthrich, H., Krug, M. \& Matthies, $\mathrm{H}$. (1987) Incorporation of [3H]-fucose in rat hippocampal structures after conditioning by perforant path stimulation and after LTP-producing tetanization. Brain Res. 410, 245-256.

4. Matthies, H. (1989) In search of cellular mechanisms of memory. Prog. Neurobiol. 32, 277-349.

5. Lössner, B. \& Rose, S. P. R. (1983) Passive avoidance training increases fucokinase activity in right forebrain base of day-old chicks. J. Neurochem. 41, 1357-1363. coproteins in the rat brain in vivo. In our study we have measured enzyme activity. Therefore, a decrease in the amount of fucokinase or inhibition of fucokinase activity may explain our reșults. The intracellular mechanisms mediating the dopaminergic receptor agonists induced by incorporation of fucose are poorly understood. It has been shown that glycoprotein fucosylation can be stimulated in vitro by dibutyrylcAMP $(14,17)$ and phorbol esters (18). However, direct addition of dopaminergic agonists ( $L$-DOPA or dopamine) and dopaminergic antagonists (haloperidol) to the enzyme assays did not alter the enzymatic activity (tab. 1). Interaction of drugs with glycoprotein metabolism is well known, e.g. the significant upregulation of liver $\beta$-galactoside $\alpha 2,6$-sialyltransferase by glucocorticoids (20). However, in our study fucosyltransferase activity is not altered; we observed drug-mediated significant changes only in rat brain fucokinase activity. So far at least four different fucosyltransferases are known, mainly determined in rat liver. In the brain up to now only one subtype of fucosyltransferase ( $\alpha-1-3$ fucosyltransferase) has been demonstrated $(21,22)$.

The unexpected finding that $L$-DOPA (decarboxylated in vivo to dopamine) decreases fucokinase activity (cortex, fig. 2) or has no effect (olfactory bulbus, striatum, thalamus and cerebellum) may be due to a receptor downregulation by receptor agonists. The opposite effect (upregulation of dopaminergic receptors) was seen after chronic treatment of rats with dopamine receptor antagonists (19).

\section{Acknowledgements}

We wish to thank Prof. Dr. $W$. Reutter, Berlin, for valuable discussion and critical reading of the manuscript. This study was supported by grants from Maria Sonnenfeld-Stiftung and the Fonds der Chemischen Industrie.
6. Büchsel, R., Hassels-Vischer, B., Tauber, R. \& Reutter, W. (1980) 2-Deoxy-D-galactose impairs the fucosylation of glycoproteins of rat liver and Morris hepatoma. Eur. J. Biochẹm. 111, 445-453.

7. Geilen, Ch., Kannicht, Ch., Orthen, B., Heidrich, C., Paul, Ch., Grunow, D., Nuck, R. \& Reutter, W. (1992) Incorporation of the hexose analogue 2-deoxy-D-galactose into membrane glycoproteins in HepG2 cells. Arch. Biochem. Biophys. 296, 108-114.

8. Jork, R., Schnmurra, I., Smalla, K.=H., Grecksch, G., Popov, N. \& Matthies, H. (1989) Deoxy-galactose mediated amnesia is related to an inhibition of training-induced increase in rat hippocampal glycoprotein fucosylation. Neurosci. Res. Commun. 5, 3-8.

9. Bullock, S., Potter, J. \& Rose, S. P. R. (1991) Effects of the amnestic agent 2-deoxygalactose on incorporation of fucose into chick brain glycoproteins. J. Neurochem. 54, $135-142$. 
10. Pohle, W., Lössner, B. \& Matthies, H. (1985) Dopamine stimulated fucosylation of rat hippocampal proteins in vitro. Biomed. Biochem. Acta 44, 527-535.

11. Dobrinsky, C., Struck, M. \& Bauer, Ch. (1983) Stoffwechsel der Fucose im perinatalen und adulten Gehirn der Ratte. Hoppe Seyler's Z. Physiol. Chem. 364, 1117.

12. Levin, L. M. \& Wei, R. (1966) Microassay of thiamine and its phosphate esters after separation by paper chromatography. Anal. Biochem. 16, 29-35.

13. Paladini, A. C. \& Leloir, L. F. (1952) Studies of uridinediphosphate-glucose. Biochem. J. 51, 426-430.

14. Bauer, Ch., Reutter, W., Köttgen, E., Erhard, K. \& Gerok, W. (1978) Decrease of serum fucosyltransferase as an indicator of successful tumor therapy. Science 201, 12321233.

15. Bauer, Ch., Hassels, B. \& Reutter, W. (1976) Galactose metabolism in regenerating rat liver. Biochem. J. 154, 141 147.

16. Jork, R., Schmitt, M., Lössner, B. \& Matthies, H. (1984) Dopamine stimulated L-fucose incorporation into brain proteins is related to an increase in fucokinase activity. Biomed. Biochem. Acta 43, 261-270.

17. Lössner, B., Jork, R., Lindner, M., Lucke, B. \& Matthies, H. (1984) Dopamine stimulated glycosylation of brain proteins in vitro is inhibited only partially by dopamine receptor antagonists. Biomed. Biochem. Acta 43, 775-787.
18. Angenstein, F., Staak, S. \& Jork, R. (1992) Phorbol esterinduced changes in rat hippocampal glycoprotein fucosylation. Neuroscience Lett. 135, 269-272.

19. Burt, D. R., Creese, I. \& Sneyder, S. H. (1977) Antischizophrenic drugs: chronic treatment elevates dopamine receptor binding in brain. Science 196, 326-328.

20. Wang, X. C., Smith, T. J. \& Lau, J. T. (1990) Transcriptional regulation of the liver beta-galactoside alpha2,6-sialyltransferase by glucocorticoids. J. Biol. Chem. 265, 1784917853.

21. Mollicone, R., Candelier, J. J., Menneson, B., Couillin, P., Venot, A. P. \& Oriol, R. (1992) Five specificity patterns of (1-3)-alpha-L-fucosyltransferase activity defined by use of synthetic oligosaccharides acceptors. Differential expression of the enzymes during human embryonic development and in adult tissues. Carbohydr. Res. 228, 265-276.

22. Mollicone, R., Gibaud, A., Francois, A., Ratcliffe, M. \& Oriol, R. (1990) Acceptor specificity and tissue distribution of three human alpha-3-fucosyltransferases. Eur. J. Biochem. 191, 169-176.

Dr. Berthold Hocher

Klinikum Steglitz der FU Berlin

Abteilung für Innere Medizin

Hindenburgdamm 30

W-1000 Berlin 45

Germany 
